\title{
Editorial
}

\section{Prospect of alternative therapies to kidney transplantation}

\author{
Jeanne A. Pawitan ${ }^{1-3}$ \\ ${ }^{1}$ Department of Histology, Faculty of Medicine Universitas Indonesia, Jakarta, Indonesia. \\ ${ }^{2}$ Stem Cell Medical Technology Integrated Service Unit, Cipto Mangunkusumo Central Hospital - Faculty of Medicine \\ Universitas Indonesia, Jakarta, Indonesia. \\ ${ }^{3}$ Stem Cell and Tissue Engineering Research Center, Indonesia Medical Education and Research Institute (IMERI), Faculty of \\ Medicine Universitas Indonesia, Jakarta, Indonesia
}

In this issue, Mochtar et $\mathrm{al}^{1}$ described the historical milestones of kidney transplantation as standard therapy of end-stage renal disease (ESRD) in Indonesia. Kidney transplantation started in 1977, and showed ups and downs, due to various causes. Though in recent years there is a growth spurt in kidney transplantation number, it is still regarded as stagnant, as the coverage is less that 3\% of ESRD cases. For patients with ESRD, available alternative approaches are hemodialysis or peritoneal dialysis, which are a life-long treatment; therefore, alternative approaches, which show comparable results to kidney transplantation are very prospective.

In recent years, stem cell therapy begins to enter human studies in Indonesia and show promises in various conditions, especially in orthopaedic cases. ${ }^{2}$ In Cipto Mangunkusumo Hospital (RSCM), other studies, which are using stem cells are ongoing, such as studies on osteoarthritis, spinal cord injury, $3^{\text {rd }}$ degree burn wound, and near blind glaucoma. For the future, stem cell therapy studies for other various conditions, which have been proven in animals, are being established; therefore, stem cell therapy and stem cell related products might become an option for ESRD in the future. A meta-analysis of the effect of stem cells on chronic kidney disease (CKD) showed beneficial effect, which might give hope to ESRD cases, as the CKD in the study had various grades and some of them represent chronic renal failure. $^{3}$

In the beginning of stem cell therapy, it was postulated that the stem cells would home to the damaged area and differentiate into the needed cells to replace the damaged cells. However, most tracing studies showed that most of the stem cells did not replace the damaged cells. Moreover, some studies showed that stem cells might not home to the site of injury, but still, there were beneficial effects due to stem cell therapy. The mechanism of cure due to stem cell therapy is mostly due to stem cell and injured cell communication, which lead to paracrine signaling. Paracrine signaling leads to secretion of various beneficial factors by the stem cells, also known a trophic factors, such as various kind of anti-inflammatory cytokines, growth factors, and various kinds of membrane bound structures in the form of microvesicles and exosomes, which contain small RNAs, in the form of micro or small interfering RNAs, beneficial peptides and proteins, and even mitochondria. Further, these factors facilitate the healing of the injured cells and tissues. ${ }^{4}$

As the mechanism of healing in most stem cell therapies is due to the stem cell secreted factors, attempts to use these stem cell secreted factors, which are known as stem cell conditioned media or secretomes or metabolites, in various studies on degenerative diseases were conducted, and a systematic review on various studies showed beneficial effects of stem cell secretomes on various conditions, including CKD. ${ }^{5}$ Stem cell secretome or metabolite has an advantage compared to the stem cell itself, as it can be stored and transported easily compared to stem cells that should be stored in a cryopreservation facility and have a limited life span in their transport medium. In the future, stem cell metabolite, which can be frozen and freeze dried without losing their growth factor content, has a great potential to be developed into drug. 
Moreover, stem cells of mesodermal lineage, the mesenchymal stem cells, have a unique additional property, i.e. immunomodulation property that is widely used to mitigate the effects of host versus graft disease, which can be advantageous in kidney or other organ transplantation. Mesenchymal stem cells are also immune tolerant, as they show low expression of MHC class I, and no expression of MHC class II, which make them to be able to evade immune surveillance, and together with their immunomodulation property render them to be safe, even though they are not HLA matched. ${ }^{6}$

In conclusion, in ESRD stem cells or their metabolites might become prospective alternative therapies to kidney transplantation, while mesenchymal stem cells might be used to mitigate the effect of host versus graft disease in kidney transplantation.

\section{REFERENCES}

1. Mochtar CA, Alfarissi F, Soeroto AA, Hamid ARAH, Wahyudi I, Marbun MBH, Rodjani A, Susalit E, Rasyid N. Milestones of kidney transplantation in Indonesia. Med J Indones. 2017;26:229-36.

2. Dilogo IH, Primaputra MRA, Pawitan JA, Liem IK. Modified Masquelet Technique using Allogeneic Umbilical CordDerived Mesenchymal Stem Cells For Infected Non-Union Femoral Shaft Fracture with a $12 \mathrm{~cm}$ Bone Defect: A Case Report. Int J Surg Case Report. 2017;34:11-6.

3. Papazova DA, Oosterhuis NR, Gremmels H, van Koppen A, Joles JA, Verhaar MC. Cell-based therapies for experimental chronic kidney disease: a systematic review and metaanalysis. Dis Model Mech. 2015;8:281-93.

4. Prockop DJ. The exciting prospects of new therapies with mesenchymal stromal cells. Cytotherapy. 2017;19:1-8.

5. Pawitan JA. Prospect of stem cell conditioned medium in regenerative medicine. BioMed Res Int. 2014;965849.

6. Faiella W, Atoui R. Immunotolerant Properties of Mesenchymal Stem Cells: Updated Review. Stem Cells Int. 2016;1859567.

pISSN: 0853-1773 • eISSN: 2252-8083 • http://dx.doi.org/10.13181/mji.v26i3.2308 • Med J Indones. 2017;26:167-8

Corresponding author: Jeanne A. Pawitan, jeanneadiwip@gmail.com

Copyright @ 2017 Authors. This is an open access article distributed under the terms of the Creative Commons Attribution-NonCommercial 4.0 International License (http://creativecommons.org/licenses/by-nc/4.0/), which permits unrestricted non-commercial use, distribution, and reproduction in any medium, provided the original author and source are properly cited. 